\title{
9 \\ The Challenges of Technology Entrepreneurship in Emerging Markets: A Case Study in Nairobi
}

\author{
Marlen de la Chaux and Angela Okune
}

\section{Introduction}

Over the past decade, national and international interest in technology entrepreneurship in Kenya has surged, in part as a result of the rapid dissemination of mobile technologies, the installation of digital infrastructure grids, and the growing consumer markets for technology in East Africa (Hussey 2015). In Nairobi in particular, computer scientists, bloggers, and technology enthusiasts have been creating and seizing opportunities to build technology businesses. To support their endeavors, a number of innovation hubs-spaces dedicated to nurturing technology entrepreneurship, usually through business incubation or acceleration-have become operational. At the same time, local and

M. de la Chaux $(\bowtie)$

University of Cambridge, Cambridge, UK

A. Okune

University of California Irvine, Irvine, US

(C) The Author(s) 2017

B. Ndemo, T. Weiss (eds.), Digital Kenya,

DOI 10.1057/978-1-137-57878-5_9 
international impact, angel, and seed fund investors have been flocking to Nairobi in hopes of identifying and sponsoring Nairobi's next big technology start-ups.

As such, the budding community around technology entrepreneurship in Kenya seems well positioned to "churn out one successful start-up after the next," as one of our informants put it. Yet, entrepreneurs, innovation hubs, journalists, and investors alike agree that creating sustainable technology businesses in Nairobi has continued to be extremely difficult (Quartz 2014; Mulupi 2013). What is more, patience is beginning to wane-and skeptics have begun voicing doubts about Nairobi's potential as the metropolitan center for East African technology entrepreneurship (Reuters 2014).

For more than 20 years now, a rich stream of research has shown that, in emerging markets, low levels of consumer demand, weakly developed financial markets, inefficient administrative systems, and underdeveloped physical infrastructures can constitute significant barriers to launching a successful business (see, e.g., Honig 1998; Pissarides et al. 2003). Although these factors may partially explain some of the difficulties that entrepreneurs encounter, our attention was drawn to another one-the relative novelty of technology entrepreneurship per se in Nairobi: The first computer science courses were introduced across the city's universities only in the late 1990s, and the spread of technology-especially mobile phones and Internet grids-began less than a decade ago (The Economist 2012). Could it be, then, that new forms of entrepreneurial activity in emerging economies - in our case, technology entrepreneurship in Nairobi - are faced with added challenges as a result of their novelty?

Drawing on an in-depth qualitative case study consisting of over 70 interviews and various written accounts, we explored the perspectives of those directly involved in technology entrepreneurship in Nairobi, i.e. technology entrepreneurs, innovation hub staff, and investors. We found that contradictory perspectives about the availability of capital, divergent views on what constituted key business skills, and misaligned perceptions of potential technology consumer markets characterized interactions among the actors involved in Nairobi's technology entrepreneurship. From our analysis, we conclude that 
these disconnects constitute an additional challenge to novel forms of entrepreneurial activity by complicating capital flows, business skills development, market identification, and thus ultimately the creation of new technology businesses.

The chapter is organized as follows: First, we provide an overview of existing research on the challenges to entrepreneurship in emerging markets, followed by a brief reflection on the nature of new forms of entrepreneurial activities. After a summary of our methodology and research context, we explicate our findings. The chapter concludes with recommendations for those seeking to foster an environment conducive to technology entrepreneurship in Nairobi (and possibly in other contexts where technology entrepreneurship constitutes a new form of entrepreneurial activity).

\section{Challenges to Entrepreneurship}

\section{Barriers to Entrepreneurship in Emerging Markets}

Emerging markets can be defined as contexts that exhibit a high pace of economic development while lacking institutional features such as stable political, financial, and legal systems; regulations; and infrastructures (Hoskisson et al. 2000). An important stream of research has investigated entrepreneurship in emerging markets and, identified four central barriers to entrepreneurship that often persist: lack of financial capital, low levels of demand for new products and services, inefficient administrative systems, and underdeveloped physical infrastructures. These constraints especially characterize sub-Saharan Africa, where business creation "is typically more difficult than in other parts of the world" (Rivera-Santos et al. 2015).

First, emerging economies tend to exhibit rudimentary and sometimes barely functioning financial markets. Often linked to more general problems of high depreciation and inflation rates (Pissarides et al. 2003), this causes difficulties in securing capital for business creation. In Kenya, for example, interest rates average around 9 percent (Julian and Ofori-Dankwa 2013; World Bank 2015b). Consequently, entrepreneurs often have no choice but to rely on personal savings or informal lending 
through their social networks in order to fund their ventures (Thornton et al. 2011).

Second, emerging markets tend to exhibit relatively low levels of demand for new products and services. Orser et al. (2000) explained that because subsistence incomes prevail in emerging markets, potential customers are less likely to risk spending the small amounts of available cash on new products and services whose functionality has not yet been confirmed by widespread adoption. In Kenya, although penetration rates for mobile phones are relatively high, consumers have been comparatively hesitant to buy technology innovations that were locally created. Instead, consumers prefer the products and services of global technology companies such as IBM, Nokia, and Huawei, which dominate mobile and software markets in Kenya (Reuters 2014).

Third, legal and administrative systems are often marked by slow procedures, corruption, and a lack of property rights enforcement (Peci et al. 2012), which make processes associated with the creation and operation of a new business time-consuming and unnecessarily costly (Aidis et al. 2012; Peng and Shekshnia 2001). Kenya ranks 136th (of 189 economies) for ease of doing business, with administrative costs for setting up a business requiring over 40 percent of the average gross domestic product (GDP) per capita (World Bank 2015a). Often, therefore, in order to save costs and time, entrepreneurs hesitate to register their new businesses, which, in turn, excludes them from property rights protection and other legal safety nets, as fragmented as they may be (Khavul et al. 2009).

Finally, infrastructures are frequently inadequate for business creation in emerging markets, impeding access to suppliers, consumer markets, and market information (Coad and Tamvada 2012). Nairobi struggles particularly with the insufficient capacity of its roads and its power grid (Blas 2013). Entrepreneurs in emerging markets may therefore incur additional costs in order to reach suppliers as well as customers. One frequently used strategy is to rely on personal networks to access market information and suppliers and to disseminate products or services through family and friends (Jack and Anderson 2002; Thornton et al. 2011). 


\section{New Forms of Entrepreneurial Activity}

In a sense, any entrepreneurial activity is new, because it consists of the discovery and exploitation of previously unrecognized but potentially profitable business opportunities (Shane and Venkatamaran 2000). Researchers, however, have distinguished several forms of entrepreneurial activity. Thornton (1999), for example, distinguished demand- and supply-driven forms. Kunkel (2001) developed a typology that distinguished between need-driven, technology-driven, low-growth-potential, income-substituting, part-time, and lifestyle forms of entrepreneurship.

In addition to motivation-based approaches, entrepreneurial activity can also be classified according to the types of new ventures that ensue (cf. Gartner et al. 1989). Social enterprises, for instance, are associated with distinctive forms of entrepreneurial activity. By combining social and market objectives, social enterprises' business models, strategies, and funding streams differ significantly from those of more traditional businesses (Austin et al. 2006). Technology businesses, similarly, are also associated with distinct types of entrepreneurial activity. A key differentiator, as Beckman et al. (2012) emphasized, is that innovations in science and engineering, rather than market demand, drive technology entrepreneurship.

When new forms of entrepreneurial activity first emerge, they may face a variety of challenges. For example, structures that facilitate the new form may not yet be in place. Social entrepreneurs, for example, initially had difficulty in formally registering their businesses, because the organizational structure blending social and for-profit values did not yet legally exist (Galera and Borzaga 2009). Similarly, reliable patenting processes for the commercialization of technologies only developed over time, as technology entrepreneurship became established as a distinctive type of entrepreneurial activity (Datta et al. 2015). Moreover, traditional stakeholders such as investors or universities may not initially understand and share the perspectives, values, or practices associated with the new forms of entrepreneurial activity. By taking stock of current developments, Cooper (1973), presented and described to the academic 
community the then-new phenomenon of technology entrepreneurship in North America.

In summary, entrepreneurial activity may be classified according to the drivers or the types of ventures created. In either case, new forms of entrepreneurial activity are associated with additional challenges, such as limited acceptance from stakeholders or a lack of legal support. However, research so far has focused on industrialized economies, where new types of entrepreneurs do not also encounter the lack of financial markets, low levels of demand, ineffective policies, and weak infrastructure that entrepreneurs in emerging markets must cope with. As a result, little is understood about the challenges associated specifically with new forms of entrepreneurial activity in emerging markets.

\section{A Case Study of Technology Entrepreneurship in Nairobi}

To learn more, therefore, we drew on an in-depth qualitative case study highlighting the challenges associated with new forms of entrepreneurial activity in Nairobi. Entrepreneurship itself is, of course, not new in the region. Informal entrepreneurs such as the jua kali (Kiswahili for "hot sun") as well as entrepreneurial activity related to agriculture and real estate have existed for decades (King 1996). However, technology entrepreneurship constitutes a new type of entrepreneurial activity. In comparison with existing types, technology entrepreneurship relies heavily on science innovations and therefore a strong technology skill and knowledge base. Nairobi's universities, however, only graduated their first computer scientists in 1997 (20 students at the University of Nairobi), 1998 (21 students at the Jomo Kenyatta University of Agriculture and Technology), and 2003 (20 students at Kenyatta University). ${ }^{1}$ In addition, unlike agriculture and real estate entrepreneurship, software and mobile technology entrepreneurship caters to consumers who already own the necessary technological hardware. A potential Kenyan consumer base for technology entrepreneurship only evolved in the mid-2000s,

\footnotetext{
${ }^{1}$ These figures were provided by our informants.
} 
following significant infrastructural improvements and the rapid dissemination of mobile phones across the country. In 2007, only 30 percent of Kenyans owned a mobile phone; in 2014, the figure stood at roughly 80 percent (Communications Authority of Kenya 2015). Finally, technology enterprises tend to compete globally, because technology innovations-particularly software and mobile-technology innovations-can be relatively independent of context (Wickham and Vecchi 2008). This further distinguishes technology entrepreneurship from many other forms of entrepreneurial activity, which tend to be localized.

Since 2010, a variety of innovation hubs have taken up operations in Nairobi to promote and facilitate the creation of technology ventures. Manske (2014) remarked on the hubs' centrality to technology entrepreneurship in the city, writing that "until 2010, around the time when iHub (one of Nairobi's first innovation hubs) was becoming a reality there wasn't much to say about the local tech ecosystem." Currently, at least six innovation hubs operate out of Nairobi.

Our case study consists of more than 70 semi-structured qualitative interviews with technology entrepreneurs, investors, innovation hub staff, and technology professionals in Nairobi, and explores their views on technology entrepreneurship. The interviews ranged from 30 minutes to 2 hours, with an average of 65 minutes apiece. In addition, Angela Okune, the second author of this chapter, served as the research director at iHub, Nairobi's largest innovation space for technology entrepreneurship, giving her detailed insight into various social dynamics over time that might have remained implicit during the interviews with some of our informants. We captured these insights in the form of a written narrative.

Taking a grounded theory approach (Glaser and Strauss 1967) —in which the theory emerges from the data rather than data confirming existing hypotheses - we analyzed our rich data by first broadly grouping pieces of information. From this, three groups of actors-technology entrepreneurs, investors, and innovation hub staff-emerged as being central to the processes and practices of technology entrepreneurship. Through iterative coding, we compared the three groups' views $^{2}$ on technology

\footnotetext{
${ }^{2}$ Although the individuals within each group naturally also expressed some degree of heterogeneity in their views, an analysis of their individual views is beyond the scope of this chapter.
} 
entrepreneurship, which revealed three recurring themes: financial capital, business skills, and market readiness. Finally, we discussed our analysis with key informants to ensure validity and reliability.

\section{Perspectives on Technology Entrepreneurship: Contradiction, Divergence, and Misalignment}

Our findings are presented in three parts. First, we bring to the surface the contradictory perspectives among technology entrepreneurs, innovation hub staff, and investors on the role of financial capital. Second, we examine the divergent understandings that the three groups have of the business skills that are crucial to technology entrepreneurship. Finally, we analyze how understandings of what constitutes a viable technology consumer market are misaligned.

\section{Too Much Seed Capital or Too Little?}

We found, perhaps most saliently, that the entrepreneurs, innovation hub staff, and investors had contradictory views about the availability of financial capital for technology start-ups. Whereas the entrepreneurs saw a disconnect between the investments they seek and the investments that are available, the innovation hub staff problematized an overall lack of capital, and the investors complained that start-ups have too much funding available.

\section{Entrepreneurs: Disconnect between Available Funding and Funding Sought}

The technology entrepreneurs spoke of three types of disconnects between the funding available and the funding sought: the accessibility of funding generally, the volume of capital needed, and the type of investment sought.

First, our data revealed that many entrepreneurs looking for investments struggled to approach investors. A survey showed that fully 75 percent of start-ups in Kenya looking for external financing did not 
contact investors (GSMA 2014). Often, this seems to have been caused by information gaps and subsequent ambiguities about where and how to approach suitable investors. As one informant explained, "The information about available funding doesn't get to the right people."

Second, many technology entrepreneurs perceived a challenge in attracting the appropriate amounts of capital. One entrepreneur said:

There's a gap for investments for start-ups who probably need something like USD100,000. Because the guys who want to invest are willing to put in at least USD500,000, you know? And there's this other side of investors who want to put in USD25,000 [or] USD10,000. And so the gap for growth and really making it matter is....lacking.

Finally, the entrepreneurs perceived a disconnect between the types of funding sought and the types of funding offered. Although capital from donations and impact investments might be available, many entrepreneurs have become wary of the associated administrative processes, often in the form of regular reports and presentations. As one technology entrepreneur explained:

I was just sent a 13-page document that asked me to compile a 100-page report to get money from a fund. I don't have the time to manage those kinds of strings attached.

\section{Innovation Hubs: Lack of Seed Capital}

By contrast, many founders and managers of innovation hubs in Nairobi perceived that an overall lack of seed capital was hampering the survival and growth of promising technology start-ups. As one hub employee elaborated: "It's capital. Even in Silicon Valley they probably say that they don't have enough capital. But it really is lacking here." Innovation hubs particularly cited the overwhelming number of start-ups - an estimated 80 percent (GSMA 2014) — that rely on personal savings or family networks for capital. Moreover, capital through bank loans is also often inaccessible, with interest rates for technology start-ups hovering at around 20 
percent (Reuters 2014). The manager of one innovation hub spelled out the consequences:

When they [entrepreneurs] run out of money, they panic and start applying for random grants and competitions. Some of them just do another [incubation or acceleration] program - totally unreasonable. They should focus on reaching their customers and making money that way instead of going from program to program.

\section{Investors: Too Much Seed Funding}

The venture capital and angel investors perceived a different reality: Instead of a lack of capital, they saw an oversupply. One informant complained that "Africa is over-flooded with money," and other investors said they have struggled with a scarcity of investment opportunities:

We have a couple of start-ups that we're interested [in] investing in and we're doing due diligence. But I'm not overloaded with so many good startups that we feel like we do not have enough money.

The investors offered two explanations for the lack of investment opportunities. First, they perceived the prominence of grants and social investments as crowding out other investments. Over the past years, the World Bank's InfoDev has disbursed multi-million-dollar grants to nurture information and communication technology (ICT) innovation in Nairobi, while impact and not-for-profit investors such as the Acumen Fund and the Rockefeller Foundation have operated their (East) African headquarters from Nairobi (InfoDev 2014; The East African 2012). A seed capital investor added:

If a start-up can get a grant from one of the development agencies, they get the money and nobody asks what they do with it. They are spoilt with all the development money. But we can't do that. We are not a charity.

Second, the investors perceived a shortage of start-ups that met their criteria. In particular, many prospective investees were missing formal 
records that conventionally form the basis of investment decisions. Many investors expressed surprise about the lack of accounting practices and business planning among start-ups and subsequently doubted entrepreneurs' ambition and trustworthiness. In one case, a seed fund manager explained that after a start-up received the funds' investment, "they stopped answering...emails; they stopped paying their staff and apparently moved to the coast with the money." Such examples, although extreme, further decrease investors' confidence in potential investment opportunities.

\section{Divergent Notions of Business Skills}

Although the entrepreneurs, innovation hub staff, and investors agreed on the importance of building technology-business skills, we found that their views of how business skills should be prioritized diverged. Whereas the entrepreneurs focused on planning and strategy, the hub staff prioritized the importance of team building and leadership, and the investors emphasized administrative and structural skills.

\section{Entrepreneurs: Strategy and Planning}

The entrepreneurs explained that the ability to iterate on a business model and product as well as selling ideas to potential investors and customers were crucial. In other words, they felt that being passionate about an idea was one component while turning the idea into a business was another:

It's easy to have an idea and you're very passionate but nobody cares. You talk to investors and angels and they're not interested. I think once you make your idea one that people care about you've got a sustainable business.

In addition to understanding how to move from idea to business, the entrepreneurs saw the creation of business structures as another key skill they lacked. Many of the entrepreneurs used start-up terms, such as "minimum viable product," "prototyping," or "fail fast," during our 
interviews. Their familiarity with such terms alone, however, seems insufficient for successfully implementing the associated business structures. One entrepreneur remarked:

Talk to the start-ups that are sitting there [co-working at a hub] and I guarantee you that not a single one of them would know their numbers. They wouldn't have anything available that investors would want to see.

\section{Innovation Hubs: Team Building and Leadership}

The innovation hub staff primarily perceived the importance of building a strong founding team. This stemmed from innovation hub staff seeing technology entrepreneurs focus on the technology aspects of their idea and, as they progressed from idea to product, realize they lacked the business skills to build a company. A member of one innovation hub's staff noted:

The most 'successful' start-ups all have at least one businessperson with a nontechnical background. If someone is working alone on their business, most likely this person won't be successful in their entrepreneurial attempt.

Almost half of Kenyan start-up founders have a technical background (GSMA 2014), and without a strong business leader on their team, such start-ups can end up fixating on technical details such as perfecting code.

Second - and closely linked to building a strong team-the hub staff perceived a lack of leadership skills among entrepreneurs. Leadership was understood to be crucial for communicating the vision of the business and attracting high-quality team members who shared a founder's vision and values. Leadership of a multidisciplinary team, however, may require founders to communicate their technological innovations and ideas in simple, effective terms to those who may be unfamiliar with technology jargon. A hub staff member explained:

It's difficult for young entrepreneurs to articulate [their vision and values] and to play that leadership role. Controlling for the quality of the idea, the next important factor is leadership. Leadership and business skills are intertwined. 


\section{Investors: Business Administration}

The investors expressed surprise at the lack of financial and administrative structures they saw among technology start-ups. A venture capital investor said:

We need to see that they keep budgets, that they keep track of their income and their expenditures, that they have a plan for income, that they have a long-term plan for returns - and they don't do that. Most of the start-ups don't track anything they do and then there is nothing you can do. Because even if I think they have potential, I can't make a positive decision. I have to justify why we...should finance them....and I can't do that if I have nothing written...if I have no accounts to show me what they are doing.

To investors, accounting and financial skills were therefore key for demonstrating a start-up's business potential. Because investors primarily use financial models to make investment decisions, the absence of financial figures captured through regular, reliable bookkeeping makes it difficult to assess the future profitability of a start-up-suggesting that when technology start-ups learn the value of good accounting, they will be more likely to receive investments.

\section{Misaligned Market Perspectives}

A company that cannot find customers to purchase its products or services will struggle to survive. Identifying the right market, however, sounds simpler than it often is. A recent poll among the founders of failed start-ups revealed that 42 percent cited a lack of a market need for their product as the primary reason for the business's failure (Fortune 2014). Despite Kenya's high mobile phone penetration, an established customer base for emergent technology innovations is still lacking. Consequently, we found that entrepreneurs, innovation hub staff, and investors have each developed their own interpretations of what constitutes a viable market for technology in Nairobi.

\section{Entrepreneurs: Fuzzy Markets}

Entrepreneurs encounter a high degree of skepticism among potential customers. Although mobile phones have penetrated daily life in Nairobi, 
many potential customers seem to remain hesitant about mobile-related innovations and other technologies. Many entrepreneurs have reported difficulties when trying to sell their technology product or service. The founder of a small start-up summarized the situation as follows:

A real challenge is market matureness. Everything else you can overcome and turn into an opportunity. This you can't. There is a widespread lack of trust in Kenyan society. That's probably the result of many years of hardening experiences. People here don't trust that your product will deliver what it's promising, and they don't believe that you'll stick around or can be taken seriously.

To overcome this barrier, a number of technology entrepreneurs have turned to what we term the nonprofit market, composed of international development agencies and nongovernmental and nonprofit organizations that have expressed interest in using technology to resolve challenges at the economic base of the pyramid. In contrast to for-profit markets, where profit is made through product sales, nonprofit markets give grants to start-ups so that they target beneficiaries, that is, those at the bottom of the pyramid who cannot otherwise afford to pay for the company's product or service. As one technology entrepreneur explained:

[For grants] you need to hit as many poor people in the slums as possible. That might be different from what angel [investors] say. They care more about whether you can actually make money out of the people in the slums whereas someone else [giving a grant] might say, "Do it all for free, just hit the numbers."

\section{Innovation Hubs: Designing for Markets}

In contrast with the lack of market readiness that the entrepreneurs perceived, the innovation hub employees found that the majority of technology entrepreneurs failed to develop adequate products for existing markets. As one hub manager said:

Honestly, the customers are there. That's not the main issue. You just have to design a product that fits what they want. 
Most hub employees explained that the majority of technology entrepreneurs failed to identify and address appropriate markets for their products and services. In particular, the innovation hub employees perceived that the majority of technology start-ups conducted insufficient market research and did not pilot their product or iterate on customer feedback. The hubs therefore emphasized the importance of tailoring products and services to customer demand and have offered a variety of mentoring opportunities to guide entrepreneurs. Innovation hub employees seemed to remain impartial about the type of markets that businesses could viably target. Whether start-ups find customers that are willing to pay for a start-up's products and services or whether they obtain grants from nonprofits to distribute their products, the hubs' main concern was that entrepreneurs frame any kind of market in the first place.

\section{Investors: Identifying Market Boundaries}

The investors tended to perceive consumer-driven markets—-that is, markets composed of individuals and businesses that purchase a start-up's products and services - to be the only viable target markets. This contrasted with the technology entrepreneurs and innovation hub staff, who also perceived the viability of designing for nonprofit markets. One investor elaborated on start-ups that tailored their products and services to the nonprofit market:

The development money, it's not helping them become sustainable. They start designing their business plan to target development agencies and not the customer, and then once the grant runs out it's a dead end. And then that makes it hard for us. Because all these companies might be run by promising entrepreneurs, but they have the wrong incentives.

Recognizing that the number of potential customers for technology goods and services may not yet be large enough to make start-ups sustainable, many of the investors therefore emphasized the importance of instead developing technology products and services for the East African market at large. In contrast to the entrepreneurs and innovation hubs, the investors thus perceived the only viable markets to be customers that purchase technology start-ups' goods and services. 


\section{Discussion: Disconnected Perspectives as Challenges to Technology Entrepreneurship in Nairobi}

In the previous section, we presented the perspectives of three key groups of actors-technology entrepreneurs, innovation hub staff, and investors-on the availability of capital, business skills, and the readiness of technology markets. To conclude, we reflect on how these disconnected perspectives may constitute additional barriers to technology entrepreneurship in Nairobi (see Table 9.1).

Table 9.1 Summary of actors' disconnected perspectives on technology entrepreneurship in Nairobi

\begin{tabular}{|c|c|c|c|c|}
\hline & Entrepreneurs & $\begin{array}{l}\text { Innovation hub } \\
\text { staff }\end{array}$ & Investors & $\begin{array}{l}\text { Subsequent } \\
\text { barrier to } \\
\text { technology } \\
\text { entrepreneurship }\end{array}$ \\
\hline $\begin{array}{c}\text { Financial } \\
\text { capital }\end{array}$ & $\begin{array}{l}\text { Disconnect } \\
\text { between } \\
\text { capital } \\
\text { available } \\
\text { and capital } \\
\text { sought }\end{array}$ & Undersupply & Oversupply & $\begin{array}{l}\text { Contradictory } \\
\text { perspectives } \\
\text { impede access } \\
\text { to funding }\end{array}$ \\
\hline $\begin{array}{l}\text { Business } \\
\text { skill }\end{array}$ & $\begin{array}{l}\text { Lack of idea } \\
\text { for market } \\
\text { development }\end{array}$ & $\begin{array}{l}\text { Lack of team } \\
\text { management }\end{array}$ & $\begin{array}{l}\text { Lack of } \\
\text { business } \\
\text { structure }\end{array}$ & $\begin{array}{l}\text { Divergent } \\
\text { perspectives } \\
\text { make skills } \\
\text { development } \\
\text { time- and } \\
\text { resource- } \\
\text { intensive }\end{array}$ \\
\hline $\begin{array}{l}\text { Market } \\
\text { readiness }\end{array}$ & $\begin{array}{l}\text { Consumer } \\
\text { skepticism } \\
\text { as an } \\
\text { obstacle }\end{array}$ & $\begin{array}{c}\text { Entrepreneurs } \\
\text { don't design } \\
\text { for markets }\end{array}$ & $\begin{array}{l}\text { NGOs and } \\
\text { donations } \\
\text { distract } \\
\text { from } \\
\text { markets }\end{array}$ & $\begin{array}{l}\text { Misaligned } \\
\text { perspectives } \\
\text { make } \\
\text { technology } \\
\text { market } \\
\text { potential } \\
\text { ambiguous }\end{array}$ \\
\hline
\end{tabular}




\section{Contradictory Perspectives: Financial Capital}

First, we found that the entrepreneurs, innovation hub staff, and investors expressed contradictory views about the availability of capital for technology entrepreneurship. Technology entrepreneurs consequently encounter an additional barrier when attempting to secure funding, namely the need to bridge these contradictory views.

Many of the entrepreneurs remarked that, incentivizing North American or European entrepreneurs to join the start-up's board or founding team meet investors' expectations and helps attract financial investments. The vast majority of angels and venture capital investors have been non-Kenyan, and merely 26 percent of investments have been made to start-ups founded by Kenyans thus far (GSMA 2014). One foreign entrepreneur explained that she built trust with another foreign investor based on their shared love of a soccer team, which ultimately secured an investment. A serial Kenyan entrepreneur summarized:

You'd be surprised by how this ecosystem works. Me and four locals trying to nail a partnership would take years. But just bring in a non-local, we just need to have them in the meeting and then we look more serious. It's a reality.

Because perspectives on the availability of capital for technology startups are contradictory, entrepreneurs incur additional (search) costs by, for instance, requiring co-founders to have certain geographical origins.

Simultaneously, innovation hub employees attempt to identify promising start-ups and connect them to capital. However, because interpretations of what constituted a start-up suitable for investments differed between the hub staff and the investors, the investors incurred additional costs by spending time and resources on start-ups that did not meet their criteria. An investor explained:

The teams that were recommended by [an innovation hub], we look at their pitch deck and it's so bad. And we're like, "You're coming from a good reference... but we can't see it." So I did three revisions on a pitch deck for a team because they were recommended to us. 


\section{Divergent Perspectives: Business Skills}

Although the entrepreneurs, innovation hub staff, and investors agreed that business skills are helpful in the creation of sustainable businesses, we found that they diverged in their interpretations of which business skills were most crucial at the onset of the entrepreneurial journey. The entrepreneurs perceived the importance of strategic planning, the hub staff considered business leadership to be central, and the investors emphasized business administration. This has several consequences for the practices associated with technology entrepreneurship. Although all business skills are likely to be helpful at some point during a start-up's development, skill prioritization is critical, given most ventures' limited time and resources. This prioritization, however, may be skewed toward the interests of innovation hubs and investors rather than the start-up's actual needs for skill development. One technology entrepreneur explained:

They [innovation hub] took us to a training for fundraising, but I didn't find it useful because my business wasn't at the stage for fundraising. At that [idea stage] moment, it's sort of a waste because when my start-up gets to that level, now I'll need that training again.

As a result of divergent views on how to prioritize business skill development, entrepreneurs may be induced to spend time and resources on, for example, attending training programs that do not immediately fit their needs in order to fulfill the expectations of innovation hubs and investors. By doing so, they demonstrate to the hubs and investors their motivation to strengthen various leadership and business administration skills. But they also drain time and resources from the actual technology start-up - meaning that divergent views on business skills become an additional barrier to technology entrepreneurship.

\section{Misaligned Perspectives: Market Readiness}

Finally, we found that views on the composition of viable technology consumer markets were misaligned between the entrepreneurs, innovation 
hub staff, and investors. This can generate even more ambiguity about market readiness, and thus constitutes an additional barrier to technology entrepreneurship. More specifically, some technology entrepreneurs tended to become trapped in a cycle where initial skepticism among consumers made the nonprofit sector appear to be the more viable market. After initial growth, the start-ups then struggled to switch from serving nonprofits and their beneficiaries to targeting paying customers (in part because investors perceived the business to be "tainted" by its nonprofit endeavors). As a result, start-ups that are designed for donors rather than for customers - that is, social enterprises and not-for-profits- to characterize technology entrepreneurship in Nairobi. This, in turn, can frustrate investors, who have, in some cases, become uncertain about the for-profit market potential in Kenya and have voiced doubts about the market focus of technology entrepreneurship.

Given the prevailing ambiguity of what constitutes a technology consumer market, many start-ups have attempted to address multiple markets simultaneously in order to generate revenue. One informant, for instance, said, "The core [technology] product is not paying enough money right now, so we have other projects - for example, a monitoring and evaluations tool for corporations to measure performance." However, maintaining a sustained competitive advantage in multiple markets simultaneously requires significant resource and capabilities, neither of which tend to be readily available to new ventures, thus making failure more likely.

\section{Recommendations for Policy and Practice: Connecting Perspectives}

In this section, we return to the initial question that motivated the chapter: What are the challenges associated with new forms of entrepreneurial activity in emerging markets? We conducted a qualitative case study of technology entrepreneurship in Nairobi, which constitutes a relatively new form of entrepreneurial activity in the region. Our analysis revealed that key actors' understandings of technology entrepreneurship do not yet align. Instead, entrepreneurs, innovation hub staff, and investors 
expressed contradictory, divergent, and misaligned views about the availability of capital, the prioritization of business skills, and the readiness of local technology markets. This, in turn, promoted the persistence of additional barriers to technology entrepreneurship:

1. Contradictory views on the availability of capital mean that entrepreneurs need additional resources (financial, temporal, and human) to bridge the contradictions and obtain funding.

2. Divergent views on which business skills are crucial at the onset of the entrepreneurial journey distract entrepreneurs from developing their start-up.

3. Misaligned views of what constitutes a viable market for technology innovations make technology markets ambiguous.

To be sure, key actors' perspectives may align over time. However, we conclude that novel forms of entrepreneurial activity in emerging markets are especially hampered by a lack of shared perspectives among key actors. Specifically, our chapter has shown that building successful technology start-ups in Nairobi remains difficult because of the contradictory, divergent, and misaligned perspectives on technology entrepreneurship.

Our analysis has concrete implications for those seeking to facilitate the creation of sustainable technology businesses in Kenya (and possibly those promoting new forms of entrepreneurial activity in other emerging markets), which we detail below. Specifically, our recommendations depart from the conventional approach of defining, measuring, and filling gaps associated with funding, skill training, and market readiness-because our analysis has found that the definitions of these gaps differs substantially between key actors, and simply filling them is therefore unlikely to facilitate technology entrepreneurship in the long term. Instead, we argue that it is important to resolve the contradictory, divergent, and misaligned perspectives among the key actors, and we offer three concrete recommendations on how to achieve this.

\section{Encourage reflection through discourse}

Greater awareness of others' backgrounds, interests and positions among the key actors, and reflection on one's own biases and expectations may help move the situation toward a middle ground where disconnected 
perspectives can in fact be connected. Initially, a handful of individuals championed the nascence of technology entrepreneurship in Nairobi, which sparked the first crucial instances of social interaction around technology entrepreneurship. As our analysis has demonstrated, however, it may now be beneficial to reflect on how the current structures of social interaction seem to perpetuate disconnected perspectives.

Discourse, especially, can facilitate reflection by enabling the various actors to voice their positions and understand those of others. Discourse can take various forms: blogging, engaging with media, events, and even simple person-to-person interactions. Although these types of interactions already occur regularly, they have too often been limited to homogeneous groups that merely reaffirm their agendas instead of engaging with those whose perspectives may be disconnected from their own. Technology entrepreneurs and hub employees, for instance, attend events at innovation hubs - events that, as a hub employee noted, are also intended for investors (though they rarely choose to attend). Meaningful discourse occurs when all actors alike take the initiative to create avenues for frequent interactions that are respectful and can ideally be beneficial to the interests of all involved.

\section{Recognize Nairobi's context-specificity}

Entrepreneurship tends to be circumstantial and highly contextspecific. Specifically, One aspect specific to technology entrepreneurship in Nairobi is the salient mix of local and international actors that we have alluded to in this chapter. Although potentially potent, the heterogeneity of the technology entrepreneurship community in Nairobi has also created significant information asymmetries. Local entrepreneurs, for instance, often complain that the computer science curricula of Nairobi's universities are outdated. Simultaneously, although the international actors tend to be equipped with technology skills, they often lack the context-specific knowledge of how to do business in Nairobi, knowledge that is often second nature to the local actors. A convergence of knowledge bases, by growing the local actors' technology business skills and the international actors' understanding of Nairobi, would reduce information asymmetries and thereby facilitate the alignment of perspectives. A straightforward way of building local technology know-how could be through updating and improving classroom curricula. Increasing the 
context-specific knowledge of international actors, however, may require a longer-term shift in mind-sets, as demonstrated by one respondent's frustration that "many investors still think people in Africa live in huts."

\section{Articulate a shared objective}

In addition, the articulation of a common objective-the creation of a sense of "we're all in this together"-may also help connect the actors' contradictory, divergent, and misaligned perspectives on technology entrepreneurship in Nairobi. Often, the actors' differing backgrounds and interests overshadow their shared common interests. Most saliently, this manifests between local and foreign actors, where the locals' mantra of "This is how we do things in Kenya" stands in opposition to foreigners' stance of adhering to their own ways of doing things. Emphasizing a larger overarching objective, such as the goal of building one of Africa's first sustainable technology entrepreneurship communities, could align the actors under a shared vision and help bridge their differences. Policymakers and technology thought leaders who reflect on the role of technology entrepreneurship in Kenya's economy at large may be especially well positioned to articulate such a shared vision. A more explicit articulation of the specificities and visions associated with technology entrepreneurship in particular might allow the nonlocal actors to root their expectations and perspectives in local realities rather than in unexamined hopes and expectations about what it might have meant to build technology businesses in Nairobi.

\section{References}

Austin, J., Stevenson, H., \& Wei-Skillern, J. (2006). Social and commercial entrepreneurship: Same, different, or both? Entrepreneurship Theory and Practice, 30(1), 1-22.

Aidis, R., Estrin, S., \& Mickiewicz, T. M. (2012). Size matters: Entrepreneurial entry and government. Small Business Economics, 39(1), 119-139.

Beckman, C., Eisenhardt, K., Kotha, S., Meyer, A., \& Rajagopalan, N. (2012). Technology entrepreneurship. Strategic Entrepreneurship Journal, 6(2), 89-93. Blas, J. (2013). Kenya has big plans for ports, power, rail and road. Financial Times. http://www.ft.com/cms/s/0/babe9838-5049-11e3-9f0d-00144feabdc0. html\#axzz3h2z7otB0. Accessed 19 Feb 2016. 
Coad, A., \& Tamvada, J. P. (2012). Firm growth and barriers to growth among small firms in India. Small Business Economics, 39(2), 383-400.

Communications Authority of Kenya (2015). Second quarter of the financial year 2014/15: Quarterly sector statistics report. Nairobi: Government of Kenya.

Cooper, A. C. (1973). Technical entrepreneurship: What do we know? R\&D Management, 3, 59-64.

Datta, A., Mukherjee, D., \& Jessup, L. (2015). Understanding commercialization of technological innovation: Taking stock and moving forward. R\&D Management, 45(10), 215-249.

Fortune. (2014). Why startups fail, according to their founders. Fortune. http:// fortune.com/2014/09/25/why-startups-fail-according-to-their-founders/. Accessed 19 Feb 2016.

Galera, G., \& Borzaga, C. (2009). Social enterprise: An international overview of its conceptual evolution and legal implementation. Social Enterprise Journal, 5(3), 210-228.

Gartner, W. B., Mitchell, T. R., \& Vesper, K. H. (1989). A taxonomy of new business ventures. Journal of Business Venturing, 4(3), 169-186.

Glaser, B. G., \& Strauss, A. L. (1967). The discovery of grounded theory: Strategies for qualitative research. Chicago: Aldine.

GSMA (2014). Digital entrepreneurship in Kenya 2014. Nairobi: GSMA.

Honig, B. (1998). What determines success? Examining the human, financial and social capital of Jamaican microentrepreneurs. Journal of Business Venturing, 13(5), 371-394.

Hoskisson, R. E., Eden, L., Lau, C. M., \& Wright, M. (2000). Strategy in emerging economies. The Academy of Management Journal, 43(3), 249-267.

Hussey, M. (2015). Silicon Savannah: How start-ups in Africa are taking on some of humanity's biggest challenges. Huffington Post. http://www.huffingtonpost.co.uk/matthew-hussey/african-startups-take-on-challenges_b_ 6416676.html. Accessed 19 Feb 2016.

InfoDev (2014). Annual report 2012-13. Washington, DC: World Bank. Jack, S. L., \& Anderson, A. R. (2002). The effects of embeddedness on the entrepreneurial process. Journal of Business Venturing, 17(5), 467-487.

Julian, S. D., \& Ofori-Dankwa, J. C. (2013). Financial resource availability and corporate social responsibility expenditures in a sub-Saharan economy: The institutional difference hypothesis. Strategic Management Journal, 34(11), 1314-1330.

King, K. (1996). Jua Kali Kenya: Change and development in an informal economy, 1970-1995. Nairobi: East African Educational Publishers.

Kunkel, S. (2001). Toward a typology of entrepreneurial activities. Academy of Entrepreneurship Journal, 7(1), 75-90. 
Khavul, S., Bruton, G. D., \& Wood, E. (2009). Informal family business in Africa. Entrepreneurship Theory and Practice, 33(6), 1219-1238.

Manske, J. (2014). Innovations out of Africa - The emergence, challenges and potential of the Kenyan Tech Ecosystem. Duesseldorf: Vodafone Foundation.

Mulupi, D. (2013). Kenya's tech industry: Over-hyped or just learning to walk? How We Made it in Africa. http://www.howwemadeitinafrica.com/kenyastech-industry-over-hyped-or-just-learning-to-walk/24767/. Accessed 19 Feb 2016.

Orser, B., Hogarth-Scott, S., \& Riding, A. (2000). Performance, firm size, and management problem solving. Journal of Small Business Management, 38(4), 42-59.

Peci, F., Kutllovci, E., Tmava, Q., \& Shala, V. (2012). Small and medium enterprises facing institutional barriers in Kosovo. International Journal of Marketing Studies, 4(1), 95-107.

Peng, M., \& Shekshnia, S. V. (2001). How entrepreneurs create wealth in transition economies. The Academy of Management Executive (1993-2005), 15(1), 95-110.

Pissarides, F., Singer, M., \& Svejnar, J. (2003). Objectives and constraints of entrepreneurs: Evidence from small and medium size enterprises in Russia and Bulgaria. Journal of Comparative Economics, 31(3), 503-531.

Quartz. (2014). Nigeria, not Kenya, is about to become Africa's next big technology hub. Quartz. http://qz.com/309891/nigeria-not-kenya-is-about-tobecome-africas-next-big-technology-hub/. Accessed 19 Feb 2016.

Reuters. (2014, December 31). Kenya’s technology push leaves investors cold. Reuters. http://www.reuters.com/article/2014/12/31/kenya-tech-idUSL6N0UE 15920141231. Accessed 19 Feb 2016.

Rivera-Santos, M., Holt, D., Littlewood, D., \& Kolk, A. (2015). Social entrepreneurship in sub-Saharan Africa. The Academy of Management Perspectives, 29(1), 72-91.

Shane, S., \& Venkataraman, S. (2000). The promise of entrepreneurship as a field of research. Academy of Management Review, 25(1), 217-226.

Thornton, P. H. (1999). The sociology of entrepreneurship. Annual Review of Sociology, 25, 19-46.

Thornton, P. H., Ribeiro-Soriano, D., \& Urbano, D. (2011). Socio-cultural factors and entrepreneurial activity: An overview. International Small Business Journal, 29(2), 105-118.

The East African. (2012). Acumen fund gets new director for East Africa. The East African. http://www.theeastafrican.co.ke/business/Acumen+fund+gets+ new+director+for+East+Africa+/-/2560/1471310/-/b1 m5j5/-/index.html. Accessed 19 Feb 2016. 
The Economist. (2012). Upwardly mobile. The Economist. http://www.economist.com/node/21560912. Accessed $19 \mathrm{Feb} 2016$.

Wickham, J., \& Vecchi, A. (2008). Local firms and global reach: Business air travel and the Irish software cluster. European Planning Studies, 16(5), 693-710.

World Bank. (2015a). Doing business: Ease of doing business in Kenya. http://www. doingbusiness.org/data/exploreeconomies/kenya/. Accessed 19 Feb 2016.

World Bank. (2015b). Real interest rate: Kenya. World Bank. http://data.worldbank.org/indicator. Accessed 19 Feb 2016. 


\title{
Conversation \#9
}

\author{
Toward a Systematic \\ Approach to Building Ventures
}

\author{
Jessica Colaço and Ibanga Umanah \\ of Brave Venture Labs
}

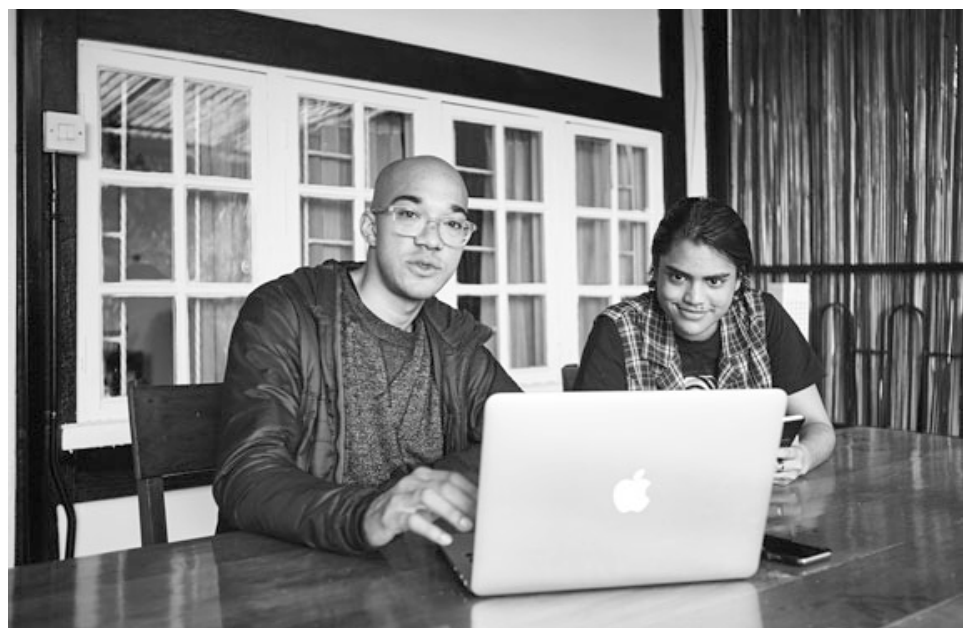

Jessica Colaço recently co-founded Brave Venture Labs, East Africa's first venture builder, based in Nairobi, with co-founder Ibanga Umanah. In 2010, she co-founded the iHub with Erik Hersman and served in various leadership positions there-as its Founding Manager between 2010 and 2011, as its Director of Partnerships and Community, and, at iHub Research, as its Research Director between 2011 and 2013. She is passionate about innovation, research, mobile and robotics technology, talent, and entrepreneurship in Kenya. She serves as an African start-up evangelist and advisor to various tech startups, 
using her position in Kenya to encourage local, regional, and international stakeholders to explore, understand, and adopt Kenyan-made and Africanmade solutions.

Ibanga Umanah partners with leaders to grow new businesses. He recently co-founded Brave Venture Labs to build new ventures from Africa. Earlier, he worked with Jump Associates (in California) to create growth strategies for Fortune 100 companies. He designed new health services for country ministries, launched technology products for logistics companies, and prototyped service innovations for retailers. In addition to Brave, Ibanga develops growth strategies for small businesses, lectures at design and leadership programs, and teaches skiing to anyone willing to fall in love with snow.

\section{Jessica, why did you decide to start Brave Venture Labs after your six years at iHub?}

JEssicA: It is difficult to summarize six years of work at the iHub in a nutshell. But during this period, I came to understand the power of networks and the serendipity effect, meaning the effect of bringing people together and watching the unexpected happen-through collaboration and learning. Every single day, I would get an email with a question that usually went like this: "I have an idea! How can I flesh it out and how can I turn this into a viable tech business?"

Two things to note. First, I am passionate about problem solving. So yes, I am the right person to address with those sorts of questions. And second, it is about talent, nurturing young talent, and unleashing their potential. The iHub provided me with a sandbox where I could experiment with talent and problems in order to solve the problems and mentor young entrepreneurs.

But eventually, six years later, it was time to move on and become more risk-taking. The new challenge that I am tackling now with Ibanga at Brave Venture Labs is matching talent with opportunities to build truly scalable and successful businesses, not just in tech but across multiple sectors - wherever we identify opportunities that are ripe for a business solution. 
During my time at the iHub, I came across a lot of talented entrepreneurs and developers as well as striking business opportunities. How do I connect the dots? This thought became the genesis of a longer discovery process, as I like to call it, in which I realized that I am a builder and connecter-someone who likes to start and create organizations and build teams in order to make it all grow and last.

A good colleague and friend of mine connected me to Ibanga. While I was in San Francisco, we actually met there and discovered that our interests and values aligned. We both have a deeper interest and motivation in creating scalable businesses and unleashing the potential of people to do the unimaginable!

\section{Ibanga, what is the motivation behind Brave Venture Labs? How did the idea emerge?}

Ibanga: In 1995, I lived with my father in Nigeria's Delta. Fights over oil had reached the highest levels and former President Abacha's cruel response left a sharp impression. As an American up until then, I saw money from my country of birth funding a government hell-bent on tearing down the lives of those close to me. I left Nigeria wanting to work on two problems in my life: How can we build organizations that are more beneficial to, and less hurtful for, individuals and society? And how can we position intelligent, ambitious people to lead those organizations?

After experimenting with a few companies of my own, I decided to tackle the first problem, initially with Ed Cohen, building a school for executives in India, and later with Dev Patnaik, creating new ventures for corporates at Jump Associates. Perhaps it is obvious to most folks, but I found corporations filled with people genuinely pursuing what they believe is right. Rare moments of corruption and breaks in ethics were often preceded by a slow erosion of purpose and empathy in leaders. So together with both Ed and Dev, we worked to instill purpose and empathy into leadership decisions and solutions. We developed new methods for understanding and building unique customer insight, for collaborating with peers to make strategic choices, and for continuously generating, prototyping, and learning in the market. Along the way, we found that 
continuously grounding ourselves in data all around us-from consumers, teams, and stakeholders-we were able to increase not only impact, but the speed of work. You might call it human-centered problem solving.

Leaders who found a clear purpose, built empathy, and continuously learned, were able to organize their teams to solve what often seemed like impossible challenges. For instance, I recently left a meeting with Ratan Tata [former chairman of the Tata Group of Mumbai] awestruck by his masterful use of purpose, empathy, and learning to solve one challenge after another. Tata's Nano project started as a sketch in his diary of a moped with a shield. Seeing families of four piled together, unprotected from wild traffic in the middle of often harsh Indian weather, was unacceptable. He believed every family should have access to safe transit. Tata took the sketch to his colleagues to experiment on solutions for what would ultimately become the world's most affordable car. His efforts have shocked automotive manufacturing and, more important, improved transportation safety for thousands. The thing is, despite all his success, he spent most of the conversation inquiring about us. I have never met a more humble and curious person. I walked away realizing his practice of humility and curiosity was what actually allowed him to notice his surroundings and continue to learn (at age 77 !). Humility and curiosity were the foundation of Tata's personal legacy of success.

Looking back, it seemed nearly all our successes, on seemingly impossible challenges, involved leaders who valued humility and continuously learned. If we were able to apply our skills in problem solving to Africa, perhaps we could accelerate the development of more human-centered problem solvers like Tata-people who seem to do the impossible.

So we founded Brave!

\section{Jessica, why is there such a strong focus on talent? And how do you ensure you match the right talent with the right opportunity?}

JESSICA: Let me explain this using some of my own experiences. In my mind, I always thought I would be coding and heavily involved in computer science-basically just writing code and building algorithms all my 
life in a lab. It was the people around me who discovered my most innate qualities and abilities. For me, the power of networks and having people around me at the right time were critical. During my time at Strathmore University, there were people like Dr. Sevilla and Edwin Nyanducha who realized I was a really good problem solver and that, at the same time, I had this affinity to organize events and bring people together. At that time, I had no clue-because I was very shy! I also did not know that I had skills in business development until Edwin pointed it out to me and threw me into the deep end of the pool with an actual business client.

Similarly with TED. I applied in 2009, and became a TED global fellow. I could not believe it! I had to go on stage in front of hundreds of people and speak about my mobile project-Wireless Map Service. The event, however, pushed me to the next level of thinking more deeply and taking on bigger challenges. Because of that challenging but positive experience, I believe in the art of unleashing the best in people. Over time, I have been able to spot talent, and by now I know by observing and giving people a few tasks what they are good at and where they need a little push to realize their full potential.

At Brave we were doing two things. On the one hand, we were creating an entrepreneurs' "forensic" map, another word for a systematic overview of their talents, individual qualities, and characteristics. By now, we have auditioned hundreds of entrepreneurs and developers and have built up a solid overview of what is out there. As a side note, we do not believe in job interviews, so we work on some challenges together with the entrepreneurs and, in that way, find out where their capabilities are. On the other hand, we identify-through systematic and rigorous research-business opportunities and work with 20 potential candidates in our challenge days on a joint investment thesis. As we progress, people who are not suitable drop out and a core group emerges.

\section{Ibanga, you want to create leaders with a particular mindset around problem solving. Why is a venture builder the right model for doing so? \\ IBANGA: We are committed to advancing leaders who take on and solve big problems. Reflecting on our work investing in and supporting}


entrepreneurs, we noticed two challenges getting in the way. One, many ideas are not scalable, usually because the original problem itself is too small. Two, teams rigidly focus on building their idea, as opposed to doing whatever it takes to solve their problem.

What do bigger problems look like? When Elon Musk was deciding what to work on after PayPal, he wrote down a list of five issues that will most affect the future of humanity: the Internet, sustainable energy, space exploration (permanent extension of life beyond earth), artificial intelligence, and reprogramming the human genetic code. Tesla and SolarCity were both founded to take on the significant challenge of sustainable energy. And while he initially focused on better electric vehicles, better batteries and solar installation were clear additions.

One of our favorite Kenyan companies, Sendy, recognized the need for access to formal goods within an informal and continuously evolving infrastructure. Most folks do not receive goods at an address, making e-commerce mostly ineffective. And between an inconsistently distributed retail sector and terrible traffic, it is costly to track down the goods you might want. Today, Sendy offers real-time, point-to-point urban deliveries using smartphones and motorbikes. But it is not inconceivable for them to manage last-mile scheduling and logistics for any kind of inventory. The challenge is enormous.

We can refer back to Tata's humility as an example of putting problems above ideas. I mentioned his original sketch was a shielded bike. It looked a bit like a fancy rickshaw. However, after two months of prototyping and testing, his team found that consumers were much more interested in an affordable car. So they shifted. As long as he was achieving affordable, safe transit, the specific idea was not important.

One might look at our challenge of creating a human-centered, learning mindset around problem solving and say, "Obviously you should pursue education for founders or young teams." But what my time spent doing new business creation and transformation at Jump taught me is that people learn through the work. The evidence continues to grow in 
this respect. Sugata Mitra showed that kids can teach themselves hard sciences with a computer in a wall. Leading A.I. developers, neuroscientists, and learning theorists like Ray Kurzweil have argued that people's natural sense of curiosity, creativity, and experimentation drive learning.

So rather than teach people to solve problems in a classroom, we will co-build companies with them. We will build to learn.

A venture builder is an ideal mechanism for learning. Generally speaking, a venture builder is a company that creates companies. In our approach, we continuously evaluate and share quantitative and qualitative market data to clarify problems entrepreneurs might tackle, then partner with a potential chief executive officer (CEO) and cocreate an idea. Together, we study the market, prototype with customers, and refine our model until we find a fit and potential for scale. We do provide some starting capital, but our CEOs are expected to raise their own funds. Like most accelerators, we have distilled plenty of business-building methods and convened the best resources in the ecosystem. However, rather than run people through a linear, time-bound, task-oriented program where everyone launches a website at the same time, we create an environment where a team can quickly access a wide variety of resources to accelerate toward a broad objective. We create metrics for achieving product-market fit or traction or positive cash flow and then convene the right mix of support for that company to achieve its goal.

In a way we are an institution of co-founders, multiplying our experience by convening the best of the ecosystem. If we are doing it right, we are increasing the level of start-up performance and generating more sustainable solutions for society.

\section{Jessica, can you walk us through the ideation process and how this all leads up to actually starting a venture?}

Jessica: Brave is kind of like a start-up studio, meaning our processes are aligned to fully flesh out and start implementing an idea that addresses a problem. Right now, for example, we are looking at a 
specific problem between commercial education and young professionals who cannot afford the education they need. So we came up with a platform idea that matches students with corporates and organizations that will issue a loan and offer future employment once the graduate completes the degree.

The process for this solution looked like this. First, Ibanga and I identify sectors with ripe opportunities. We looked particularly at the middle to upper class in Nairobi. Through industry-sector reports from PricewaterhouseCoopers and Deloitte, we narrowed the focus to particular sectors. In fact, with Brave, we are looking at five sectors at the moment-health, finance, agriculture, tourism, and education. Now we dig even deeper into each sector, conducting market and customer research to understand the dynamics. This process is completely self-funded. In health, for example, we want to focus on preventive health care, in finance on peer-to-peer lending, in agriculture on food trading and food wastage, in tourism on domestic tourism, and, as I mentioned, in education on the commercial side of higher education.

After that we conduct a challenge day with 20 individuals-entrepreneurs and developers - who understand the sector, and we note down all assumptions each business idea has. We formulated a research poster (6 by 4 feet) with all this information and walked each individual through our process to get the thinking started. Picture it as a collective brainstorming session in which we test business ideas in order to come up with a clear overview on the problem, the opportunity, and the "right" business idea.

The next step is a written opportunity abstract, forming an investment thesis that we use as a basis to sources the right talent-these are co-founders with whom we create the business to get the implementation started. Once all the founders are on board, Brave will co-build the business with the co-founders and get to work. 


\section{Ibanga, what are some of the tools you use to affect this mindset change and why, in your opinion, are those in particular of value?}

IBANGA: We continuously pull principles and practices from as many disciplines as possible, as opposed to following one idea to the letter. And often, several disciplines form a unique approach to achieving the same end.

For example, think of all the different ways we talk about "keeping an open mind" so we can learn:

- Neuroplasticity

- Beginner's mind

- Growth mindset

- Rapid prototyping

- Vertical learning

- Creative intuition

- Mindfulness

- Mental flexibility

Neuroplasticity proposes that the human brain continues to change over the course of its life. As we age, experience new things, and challenge ourselves, we continue to learn. In other words, you are never done learning.

Beginner's mind, a concept from Zen Buddhist philosophy, asks that we continue to see the world around us from the point of view of a child. If we look at people or experiences as if we were a beginner, we might notice new nuances and continue to learn.

Carol Dweck teaches folks to look at themselves and their teams as having the potential to learn with practice rather than seeing people as "born talented" or not. Folks with a growth mindset see failure as an opportunity to learn and get better. So we can continue to challenge ourselves and each other to learn something new from any experience. 
Rapid prototyping, as applied to solutions beyond 3D models, approaches product design like a science experiment. We make observations and generate predictions about what might work-otherwise known as having ideas! Then we develop tests to see what works and what does not and improve our ideas. By quickly and cheaply gathering data to iterate, we increase our chance of market performance before running out of money. We learn from and improve with every attempt. Said another way, we actively learn from failure.

Information and techniques from every one of these areas will be useful as we go about the work of developing new business ideas. We will use the same multidisciplinary mash-up for how to best research customers, work in teams, optimize systems, and so on.

\section{Jessica and Ibanga, is the venture builder addressing a niche in Kenya in particular or do you see this approach as being useful globally?}

IBANGA: Continuous learning and the hybridization of disciplines to solve problems are useful globally. My friends in San Francisco continue to combine the best of social science and data science to construct better ways of working, the best engineering and design to create better experiences, and the latest business strategies and psychology to build businesses models around new behaviors. And although I practiced it there, it is almost certainly happening in every creative economy around the world.

For example, in 1978, Nicholas Negroponte and colleagues at MIT received government funding to create digital tools to familiarize soldiers with remote locations. Building off of some work by early filmmakers, the Aspen Movie Map team built a camera array on a car, drove the streets of Boston, and using the then-new technology of laserdiscs (which could associate a location tag with a specific point on the disc), created a virtual, searchable map of the city. Building on the idea more than 25 years, later Larry Page used the technology to create Google Street view. Basic legal practices and publishing had effectively allowed filmmakers, government, academics, and start-ups to collaborate on creating one of the most widely used products today. 
The opportunity for Kenya, and I imagine for most countries, is the ongoing practice of making it easier and culturally "okay" for this kind of collaboration to take place and be fruitful.

JEssica: Our idea is not to stay in Nairobi. We see our longer-term task as connecting the dots on a pan-African scale. Once the first two companies are up and running, we will move to other cities across the continent, directed by market dynamics and our network's strength. Right now, the destination for our next set of companies would be Ghana, Nigeria, or South Africa.

\section{Ibanga, what are the crucial ingredients needed to build a venture that can advance society?}

IBANGA: There are two parts of a new venture to consider, broadly speaking. First, solve a problem for people with an innovative model, experience, and/or technology. How innovative you need to be really depends on the problem. Second, organize people in an institution to execute. Every business is a structure for a group of people to work together.

You might think of our role in the second part as similar to how US insurance companies manage care networks. Using a combination of real-time data and frequent contact with members, they evaluate performance and negotiate rates with the best mix of services required to quickly address a particular disease. When successful, in addition to reducing prices for patients, they can streamline a care pathway and boost the overall quality of treatment.

At Brave, we work to evaluate and convene new-business ecosystems, including lawyers, accountants, and subject-matter experts, to stand up, operate, and grow companies-faster, smarter, and at lower costs.

Creative problem solving is also systematic in a sense but should be seen more as a continuous-learning model than as a linear flow of activities. On some level, the analogy for us here is the scientific method. We attempt to understand the world, create hypotheses, conduct experiments, 
allow our views to evolve based on new information, and continuously update our solutions.

If we stop there, we just get the ventures. So, to the second part: if you want any human system, including entrepreneurship, to advance you need two more things. First, many people experimenting with their own approaches in a variety of settings. And two, previous discoveries documented and shared so the next generation can critique and advance that work.

The truth is, there is no shortage of intelligent, exploratory entrepreneurs in Kenya. The challenge is recording and exposing what they have learned so that how we work can be improved. The faster we can make the learning cycle, the better we can become.

As a normal practice of creating ventures, Brave is deeply involved in both listening to and learning from respected entrepreneurs as well as encouraging experimentation and improvement in every new generation of builders.

\section{Thank you, Jessica and Ibanga!}

\footnotetext{
(ब) (1) This chapter is distributed under the terms of the Creative Commons Attribution 4.0 International License (http://creativecommons.org/licenses/by/4.0/), which permits use, duplication, adaptation, distribution and reproduction in any medium or format, as long as you give appropriate credit to the original author(s) and the source, provide a link to the Creative Commons license and indicate if changes were made.

The images or other third party material in this chapter are included in the work's Creative Commons license, unless indicated otherwise in the credit line; if such material is not included in the work's Creative Commons license and the respective action is not permitted by statutory regulation, users will need to obtain permission from the license holder to duplicate, adapt or reproduce the material.
} 